\title{
Multicriteria Approach towards the Sustainable Selection of a Teahouse Location with Sensitivity Analysis
}

\author{
Ji Chen ${ }^{1}$, Jinsheng Wang ${ }^{2, *}$, Tomas Baležentis ${ }^{3, *}{ }^{\mathbb{D}}$, Fausta Zagurskaite ${ }^{3}$, Dalia Streimikiene 4 (i) \\ and Daiva Makutèniené ${ }^{5}$ \\ 1 College of Statistics and Mathematics, Zhejiang Gongshang University, Hangzhou 310018, China; \\ chenji810404@mail.zjgsu.edu.cn \\ 2 School of Business, Zhejiang Wanli University, Ningbo 315211, China \\ 3 Faculty of Economics and Business Administration, Vilnius University, LT-10222 Vilnius, Lithuania; \\ Faustazagurskaite@gmail.com \\ 4 Lithuanian Institute of Agrarian Economics, LT-03105 Vilnius, Lithuania; dalia@mail.lei.lt \\ 5 Faculty of Economics and Management, Aleksandras Stulginskis University, LT-53361 Akademija, Lithuania; \\ daiva.makuteniene@asu.lt \\ * Correspondence: wjsdxc@zwu.edu.cn (J.W.); tomas@laei.lt (T.B.)
}

Received: 6 July 2018; Accepted: 14 August 2018; Published: 17 August 2018

\begin{abstract}
The teahouse market has seen an expansion across various countries. In order to identify the most reasonable paths for development, the choice of location for the outlets needs to account for a number of conflicting criteria. Therefore, the multicriteria approach is required to effectively handle the location selection problem. In this paper, we develop a multicriteria framework for teahouse selection and apply it in the context of Lithuania. The indicator system is set up in order to capture the different aspects of the candidate locations. We also apply two multicriteria decision-making techniques (the evaluation based on distance from average solution (EDAS) method and the weighted aggregated sum product assessment with normalization (WASPAS-N) method) in order to ensure the robustness of the results. The weights of criteria were determined based on the expert survey. In addition, a Monte Carlo simulation was applied to check the sensitivity in changes of the criterion weights. The empirical application demonstrated validity of the proposed approach in choosing the optimal location of a teahouse.
\end{abstract}

Keywords: teahouse; location selection; multicriteria decision making; Monte Carlo simulation

\section{Introduction}

The hospitality sector is an important contributor to economic growth as it creates jobs, generates income, and facilitates international connections in multiple ways [1-4]. This sector is even more important for countries without fossil resource endowments. Lithuania may be a good case for the promotion of the hospitality sector. The food and beverage service is an important component of the hospitality sector. According to Statista [5], the turnover of the Lithuanian food and beverage service sector reached 512.9 million Euros as of 2014. The corresponding figure for 2013 was 474.7 million Euros. What is more, at the end of 2015, 980 enterprises for the manufacturing of beverages were in operation in Lithuania, with $20.9 \%$ of them being individual. The period of 2011-2015 saw an increase in the total number of enterprises by $16.3 \%$, whereas the number of individual companies rose by $1.5 \%$ [6]. In order to ensure the further expansion of the Lithuanian hospitality industry, new forms of hospitality businesses need to be promoted. The teahouse could be a new niche for the hospitality sector. Statista [5] also reported the compound annual growth rate of 2.6\% for the European tea market 
during the period of 2018-2023. Turning to Lithuania, the revenue generated in the tea subsector amounted to more than 31 million Euros in 2018 [7]. In addition, there has been a decline in the coffee market as the revenue generated there decreased by $4.6 \%$ according to Nielsen [8].

The teahouse can be considered as an appealing option for the hospitality sector development in Lithuania for the market for specialized teahouses in Vilnius has not been saturated yet. For instance, there are just nine teahouses in Vilnius as opposed to the 66 coffeehouses there, according to the results of a Google search. On the contrary, it is known that coffee market in Lithuania is dominated by chain cafes like Caffeine, Vero café, Presto, and so on. The case of Starbucks also showed that the coffee market in Lithuania is already saturated, as this brand decided not to come because of enormous competition [9]. The trend of the development of teahouses is indeed prevailing in Europe. People are becoming more concerned about the status of their health, and they are more prone to consider their food and drink rations. Some studies have suggested that tea is a healthier option and can cause a reduction in the probability of heart diseases as suggested by a survey by Gardner et al. [10]. What is more, it can interact with cancer according to Ek et al. [11]. Following the trend of healthier living is a great opportunity for entrepreneurs and investors. Therefore, the development of methodologies for the choice of a teahouse location can be of benefit to future investors and entrepreneurs.

The location selection is a multicriteria problem, which requires appropriate methodology. Multicriteria decision-making (MCDM) techniques can be applied to handle problems of location selection, taking multiple conflicting criteria into consideration. Location selection problems focused on infrastructure objects (airports, service facilities) have been addressed by means of MCDM techniques: Sennaroglu and Celebi [12] applied PROMETHEE (Preference Ranking Organization METHod for Enrichment of Evaluations) and VIKOR (Vlsekriterijumska Optimizacija I KOmpromisno Resenje) techniques for airport location selection; Nguyen Anh and Hoang Thi [13] utilized technique for order of preference by similarity to ideal solution (TOPSIS) for choosing the location of a distribution center; hybrid approaches involving analytic hierarchy process or analytic network process were applied by Chang et al. [14], Ertuğrul and Karakaşoğlu [15], Hu et al. [16], and Yıldız and Tüysüz [17]. The hospitality sector has also been analyzed in this regard by applying linguistic reasoning [18], fuzzy logics [19,20], non-compensatory measures [21], and hybrid MCDM techniques [22]. However, the problem of teahouse location selection has not received appropriate consideration in the literature. In order to promote the development of the hospitality sector in this regard, this paper proposes an MCDM-based framework.

The research aims to propose a framework based on MCDM methods for effectively handling the problem of location selection for a teahouse. The following research goals were implemented: (1) to analyze the main concepts underlying the MCDM methods; (2) to identify the specific methods to be adapted to the teahouse location selection problem; (3) to determine the criteria for solving the problem of the location selection; and (4) to apply the chosen methods when implementing the model for effective solution of the problem of the teahouse location selection. The criteria for location selection were determined following the literature review. The case of Vilnius (Lithuania) is considered in the empirical example with alternative locations chosen from the real estate database. The weights of criteria were set on the basis of the expert survey and Monte Carlo simulation.

The two MCDM techniques, namely the evaluation based on distance from average solution (EDAS) method and the weighted aggregated sum product assessment (WASPAS) method, were applied for the ranking of the alternatives. The use of these techniques allows the checking of the robustness of the results with regards to different normalization principles and utility functions. More specifically, the EDAS technique relies on the reference point approach, whereas the WASPAS technique applies value functions (additive and multiplicative utility functions). The proposed framework may help establish businesses in the tea market by taking into account the multiple alternatives and expert assessments. It is noteworthy that the proposed approach may be adapted to different contexts and applied in different locations. Methodologically, we revised the WASPAS 
technique by involving an additional stage of normalization when aggregating the additive and multiplicative utility functions.

The paper proceeds as follows. Section 2 comprises a review of the development and applications of the MCDM techniques. In this part, the theory and applications of MCDM for the location selection are discussed in detail. Section 3 focuses on an overview of the specific MCDM methods chosen for solving the location selection problem and their theoretical aspects. Section 4 presents the main results. Finally, Section 5 presents the concluding remarks.

\section{The Preliminaries for MCDM and Its Application for the Location Selection Problems}

This section comprises the two main parts. The first subsection is devoted to a more general discussion on the nature of the MCDM techniques and the main theoretical principles to be followed. The second subsection discusses the possibilities of the application of the MCDM techniques for solving the location selection problem, which is a focal point of this research.

\subsection{MCDM Methods}

In this subsection, we briefly present the major strands in MCDM. MCDM problems have several common features. First, MCDM considers multiple objectives represented by the corresponding criteria, and the decisionmakers are allowed to establish conflicting relationships among these criteria. Second, the criteria to be considered are expressed in different dimensions (units of measurement), which does not allow for a trivial aggregation of the decision matrix. Third, the MCDM problems consider multiple alternatives that represent socio-economic decisions at different levels. The presence of the aforementioned properties implies that one has to handle multidimensional problems. In this case, decision making can rely on different types of the MCDM methods [23]. The MCDM methods are primarily aimed at quantifying the underlying utilities and ranking the available alternatives. However, different MCDM methods can result in different outcomes (i.e., the same set of alternatives might be attributed with different rankings). This can be attributed to different mathematical operations employed by the considered methods. Therefore, the issue of identifying the most suitable MCDM method for a particular case still exists [24].

The MCDM methods can be further divided into multi-objective decision-making (MODM) methods and multi-attribute decision-making (MADM) methods [25]. The MODM methods deal with continuous optimization problems (i.e., the best alternative is chosen from infinite set of alternatives). However, integer programming might be applied to a discrete set of alternatives. Conversely, the MADM methods can only handle discrete sets of alternatives. However, the literature usually refers to the MADM methods as the MCDM methods (we follow this strand in the other sections of this paper too).

The MADM methods can be grouped into those based on the value function, reference point, and outranking [26]. The techniques based on the value function include simple additive weighting [27], weighted product method [28], multi-attribute utility theory (MAUT) [29], and the weighted aggregated sum product assessment (WASPAS) [30]. These techniques aggregate the normalized values of the decision matrix by taking the weighting associated with the criteria into consideration. The analytic hierarchy process (AHP) by Saaty [31] can also be considered as a value function-based approach [32]. The technique for order of preference by similarity to ideal solution (TOPSIS) [33] and VIKOR [34] can be given as examples of the reference point-based approaches. In this case, the distances among the alternatives and ideal solutions (reference points) are measured. TOPSIS relies on Euclidean distance, whereas VIKOR involves Manhattan and Chebyshev distances. Certain generalizations are possible. For instance, the Multi-Objective Optimization by Ratio Analysis (MOORA) technique [35] involves both the reference point approach and value function approach. The evaluation based on distance from average solution (EDAS) approach [36] considers the average solution as the reference point. Finally, the outranking approaches include methods based on preference relationships (e.g., ELECTRE (ELimination Et Choix Traduisant la REalité) [37] or PROMETHEE [38]). 
As regards the continuous optimization and the MODM methods, Marler and Arora [39] presented a survey on MODM techniques. The different utility functions can be employed to aggregate the objective functions in MODM. Therefore, one can arrive at a weighted-sum model or a weighted-product model, among other formulations. Lexicographic models define the ordering of the objectives without quantitative considerations. The objective functions can also be defined in a number of ways. For instance, Romero et al. [40] linked the goal programming, compromise programming, and reference point formulation. Sawik [41-43] applied weighted-sum and lexicographic approaches in connection with mathematical programming for decision analysis.

For more detailed reviews on the use of different MCDM techniques one can consult papers by Kumar et al. [25], Diaz-Balteiro et al. [44], Zavadskas, Turskis [45], Song et al. [46,47], and Marler and Arora [39]. As we focus on the location selection for a teahouse, the set of alternatives is finite and determined by the supply of the premises. Therefore, we apply the MADM approach, and the term MCDM will refer to the MCDM methods in the following sections. Among the possible techniques for MADM, there is a need for choosing the methods that allow the aggregating of the decision information by applying different principles (i.e., normalization, utility functions) in order to ensure the robustness of the analysis.

\subsection{Location Selection and MCDM}

There has been a body of literature on the application of MCDM techniques in the domain of location selection [48,49]. The MADM was applied by implementing different techniques for discrete sets of alternatives (locations). The fuzzy logic and preference relations were involved into the choice of the distribution center location by Chen [48] in order to account for uncertainties in the decision information. The triangular fuzzy numbers were applied to map the linguistic variables to the fuzzy values. The fuzzy numbers were used to represent the ratings, weights of criteria, and the resulting utility values. The fuzzy preference matrix was established in order to compare the alternatives via the step-wise approach. Cagri Tolga et al. [49] tackled the retail location selection problem by proposing a fuzzy MCDM procedure relying on the analytic network process. The application of the fuzzy MCDM in the hospitality sector can be found in the study by Chou et al. [19]. The latter study offered a fuzzy MCDM procedure for choosing the hotel location considering such variables as geographical properties, traffic conditions, hotel requirements and performance in terms of operation management. Tzeng et al. [50] applied AHP and VIKOR for restaurant location selection. Ziemba et al. [51] and Ziemba [52] proposed a fuzzy PROMETHEE-based technique for selection of a wind farm.

The problem of location selections has also been addressed by means of the MODM. The integer programming model was also set up by Jovanovic [53] for optimization of the electricity grid. Specifically, the decision variables included both the location and capacity of the transformer. The parameters of the model included investment costs (per annum), voltage fluctuations, load of feeders, and substations. The data envelopment analysis was combined with the integer programming model [54] in order to facilitate the identification of the most promising location for investment and implementation of a project. Indeed, data envelopment analysis defined the Pareto efficient frontier based on multiple criteria, whereas the integer programming problem can identify the most desirable combination of the decisions with regards to the efficiency frontier. Another application of the integer programming problem can be found in the study by Bhaumik [55]. The latter study aimed to identify the nodes of a distribution network to be shut down given the locations of the distributors and retailers. Tzeng and Chen [56] operationalized the choice of number and locations of fire stations within an international airport via the fuzzy multi-objective model. In order to tackle the complexity surrounding the fuzzy problem, a genetic algorithm was applied and juxtaposed to the enumeration method. Arora and Arora [57] and Serrano-Hernandez et al. [58] applied mathematical programming for plant location problems in different contexts. Ho et al. [59] combined AHP and multi-choice goal programming for solving the problem of restaurant location choice. 
There has also been a body of literature focusing on the outlet (e.g., store or restaurant) location problems. The main principles underlying the issue of the retail location problem have been discussed by Nelson [60]. The rents attributed to stores were analyzed by Applebaum and Cohen [61] with regards to the store sites. The use of the multiplicative competitive interactive approach was advocated by Jain and Mahajan [62] when analyzing the competitive environment in the retail activities. The approach for measurement of the service quality (SERVQUAL) was applied by Hing and Lee [63] in the context of restaurant operation. The quality of the hospitality management services was assessed by Olsen and Roper [64]. The latter study also looked into the strategic management issues amidst the effects of globalization, multinationals, and corporate strategies. An approach integrating fuzzy numbers and the analytic hierarchy process was proposed by Kuo et al. [65] in order to select the most suitable location for a convenience store. The optimal location of the new franchises among the existing ones has been tackled by means of multi-objective integer programming [66]. Such criteria as customer flow and the presence of competing outlets were considered in their model.

Therefore, the location selection problem is topical across different sectors and levels of aggregation. The problems of the location selection rely on different theoretical preliminaries and research methods. The use of the MCDM techniques is needed to effectively handle the multiple effects of the feasible solutions. In the context of the present study, the choice of the teahouse location can be formulated as an MCDM problem.

\section{Framework for Multicriteria Choice of the Teahouse Location}

Deciding which location is the best one for expanding a business is a complicated process, and it includes multiple conflicting factors [67]. From the techniques available for solving MCDM problems, one needs to choose the suitable ones for addressing particular problems. In this study, EDAS and WASPAS-N methods are to be used for solving the location problem. In this section, the two MCDM techniques will be presented in a more detailed manner. The main properties of the underlying utility functions will be discussed, which allow one to understand the major differences between these two techniques.

This study focuses on the case of teahouse location selection. This problem is a multicriteria one, as multiple conflicting objectives arise when comparing different locations. Specifically, the economic, social, and environmental criteria can be regarded as those determining the attractiveness of a certain location. The criteria defining the objectives of the business are also expressed in different dimensions. Finally, the importance of different objectives might vary. All these circumstances imply the need for multi-criteria analysis.

In this section, the framework for the multicriteria choice of a teahouse location is presented. First, the two MCDM methods are presented. Second, the approach for sensitivity analysis involving simulation of the random vectors of the criteria weights is discussed. This kind of sensitivity analysis enables one to look into the stability of the vector of ranks as the vector of weights is changed. Note that we also provide the weights of criteria based on an expert survey. Experts were given a questionnaire based on a Likert scale (scores from 1 to 5 ).

\subsection{Indicator System}

The identification of the best location is a critical step in cost/benefit analysis framework for any coffee/teahouse, restaurant or other food and drink service outlet [68]. Nevertheless, there exists a variety of various different goals underlying the problem of location selection. A teahouse not only provides a selection of different types of tea or snacks but is also important in the sense of communication and social interaction in general. The success of a teahouse is led by an appropriate location. It goes without saying, that the level of the convenience of service and, hence, the number of potential customers is critically related to the choice of the place of operation. Therefore, selecting the location of an outlet is of high significance when deliberating on buying or renting suitable premises for 
food or drink businesses. In most cases, the issue of selecting location can rest on the past experience or the opinion from experts [69].

To mitigate the shortcomings of intuition judgements, or even to control costs and indicate perks of alternative locations, it is handy to adopt a scientific method. The location selection of a teahouse is quite diverse from common selection decisions. This is because of the complexity of the issue; the problem deals with customer uniqueness, competitors, or even costly decoration. It is known that the tea market in Lithuania is not as saturated as the coffee market; however, there are still many issues that must be faced. Indeed, in order to select an eligible site for a teahouse business, both quantitative and qualitative criteria are required to be considered simultaneously [70]. For these reasons, this study presents a quantitative assessment tool to assist tea market players in choosing the most promising location for acquiring a property for a teahouse in terms of both quantitative and qualitative aspects.

Location selection is usually initiated once the need for additional capacity is realized [71]. This triggers the process of searching for the optimal solution with regard to the new premises. The factors that determine the overall utility of a certain alternative (i.e., location) generally fall in the following groups: market available, transportation network, labor supply, surrounding site, availability of raw materials and services, access to utilities, the presence of regulations, and the community environment. Nevertheless, these categories are not fully suitable for solving the teahouse location problem. Thus, it is clear that the issue to be tackled in this study is a bit more specific.

The inflow of customers and the prospective growth of the business is impacted by such factors as access to the public transport (buses, trolleybuses) and the availability of parking spaces for private transportation near the teahouse, landscaping, distance from public facilities, and the size of the property and commercial area. This research, thus, seeks to develop a MCDM framework for ranking of the alternative locations for a teahouse. The framework includes the following: decision criteria, alternative locations, and weighting of the criteria. The empirical example considered is the teahouse location problem for a teahouse in Vilnius, Lithuania. The literature review was carried out in order to identify the criteria for the empirical research. The resulting set of indicators is outlined in Table 1.

Table 1. Criteria for the choice of a teahouse location.

\begin{tabular}{lc}
\hline \multicolumn{1}{c}{ Criteria } & Sources \\
\hline 1. Rent cost & {$[50]$} \\
\hline 2. Property area & {$[59,72]$} \\
\hline 3. Distance to scenery & {$[73]$} \\
\hline 4. Public transportation & {$[50]$} \\
\hline 5. Pedestrian flow & {$[50,65]$} \\
\hline 6. Parking capacity & {$[50,65]$} \\
\hline 7. Number of competitors & {$[50,65]$} \\
\hline 8. Number of crimes in the surrounding area & {$[19,74]$} \\
\hline 9. Distance from public facilities & {$[19,50]$} \\
\hline 10. Outdoor advertisement & {$[50,65,73]$} \\
\hline 11. Distance from garbage containers & {$[50]$} \\
\hline
\end{tabular}

It is well known that the cost of property and its area are the main criteria for location selection; nevertheless, the decision also depends on many other criteria. In this paper, the cost of the property is expressed as the amount of money that must be spent to rent the space per month, and the property area is expressed as the inner space of the available area for rent $\left(\mathrm{m}^{2}\right)$. Focusing on the customers, teahouse customers arrive on foot or by public or private transport. Therefore, these options should be accounted for during the analysis. The pedestrian flow is included as a criterion in order to identify the possible flow of clients that arrive on foot. The availability of parking spaces is also included 
a criterion in order to identify the possibilities for arrival of customers relying on private transport. In this case, the capacity of the parking space within $500 \mathrm{~m}$ around the candidate location is considered. The access to public transport is also included in the model in order to capture the possible customer flow relying on the use of public transport. The access to public transport is quantified by considering the frequency of arrival of public transport in vicinity of the candidate location. Distance to scenery is yet another factor that can increase the attractiveness of the candidate place, even though the current customer flows are subdued. Therefore, this criterion is also included in the analysis. Similarly, the number of crimes in the area is also likely to shape the flows of customers. The distance from the public facilities is included into the model in order to account for possible customer inflow.

The economic performance of the teahouse is impacted by the competitive environment. Therefore, the number of competitors enters into the MCDM model. It is measured as the number of similar teahouses within the radius of $500 \mathrm{~m}$ [62]. The possibilities for outdoor advertising depend on the regulations prevailing in the area. Indeed, this might also imply changes in the competitiveness of the outlet. We include the area of possible outdoor advertisement as the corresponding indicator. The disposing of the waste generated during the process of operation is related to both economic and environmental dimensions (and, eventually, the social one) of the teahouse business. Therefore, the criteria for distance to the garbage containers can be considered as yet another measure for the sustainability of the operation of a teahouse.

\subsection{EDAS Method}

The evaluation based on distance from average solution (EDAS) method was proposed by Keshavarz Ghorabaee et al. [36]. The EDAS technique can be identified from the other methods in that it relies on the measurement of the distances from the average solution rather than the ideal ones. In this regard, the decision space is less impacted by the outlying observations. The measures of the positive distance from the average (PDA) and negative distance from the average (NDA) are applied in order to define the relative performance of the alternatives considered with respect to multiple criteria. Indeed, the alternatives showing higher (resp. lower) values of PDA (resp. NDA) are more preferred. Keshavarz Ghorabaee et al. [75] extended the EDAS technique into the fuzzy environment.

Let there be $n$ alternatives and $m$ criteria. The EDAS method then proceeds in the following way: Step 1 . The decision matrix is constructed. For instance, the rows represent the alternatives and the columns represent the criteria as follows:

$$
X=\left[X_{i j}\right]_{n \times m}=\left[\begin{array}{cccc}
X_{11} & X_{12} & \cdots & X_{1 m} \\
X_{21} & X_{22} & \cdots & X_{2 m} \\
\vdots & \vdots & \vdots & \vdots \\
X_{n 1} & X_{n 2} & \cdots & X_{n m}
\end{array}\right]
$$

where $X_{i j}$ denotes the value defining the rating of the alternative $i$ with respect to the criterion $j$ with $i=1,2, \ldots, n$ and $j=1,2, \ldots, m$, where $n$ and $m$ are the numbers of alternatives and criteria, respectively.

Step 2. For each criterion, calculate the average solution:

$$
A V=\left[A V_{j}\right]_{1 \times m}
$$

where each component of $A V$ is obtained as follows:

$$
A V_{j}=\frac{\sum_{i=1}^{n} X_{i j}}{n}
$$


Step 3. The relative positions against the average solution are obtained in the form of PDA and NDA. The following matrices store the results:

$$
\begin{aligned}
P D A & =\left[P D A_{i j}\right]_{n \times m} \\
N D A & =\left[N D A_{i j}\right]_{n \times m}
\end{aligned}
$$

The elements of the matrices defined by Equations (4) and (5) depend on the type of the criteria. If the $j$-th criterion is benefit one, then the following is true:

$$
\begin{aligned}
P D A_{i j} & =\frac{\max \left(0,\left(X_{i j}-A V_{j}\right)\right)}{A V_{j}} \\
N D A_{i j} & =\frac{\max \left(0,\left(A V_{j}-X_{i j}\right)\right)}{A V_{j}}
\end{aligned}
$$

If the $j$-th criterion is cost one, then the following is true.

$$
\begin{aligned}
P D A_{i j} & =\frac{\max \left(0,\left(A V_{j}-X_{i j}\right)\right)}{A V_{j}} \\
N D A_{i j} & =\frac{\max \left(0,\left(X_{i j}-A V_{j}\right)\right)}{A V_{j}}
\end{aligned}
$$

where the positive and negative distances for alternative $i$ with regards to criterion $j$ are denoted by $P D A_{i j}$ and $N D A_{i j}$, respectively.

Step 4 . The positive and negative distances obtained for each alternative are aggregated by applying the weighted sum. Therefore, $S P_{i}$ and $N P_{i}$ denote the two weighted sums:

$$
\begin{aligned}
& S P_{i}=\sum_{j=1}^{m} w_{j} P D A_{i j} \\
& S N_{i}=\sum_{j=1}^{m} w_{j} N D A_{i j}
\end{aligned}
$$

where $w_{j}$ is the weight associated with criterion $j$.

Step 5. The aggregates obtained in Step 4 are normalized with respect to the maximum values in the following manner:

$$
\begin{gathered}
N S P_{i}=\frac{S P_{i}}{\max _{i}\left(S P_{i}\right)} \\
N S N_{i}=1-\frac{S N_{i}}{\max _{i}\left(S N_{i}\right)}
\end{gathered}
$$

Step 6. Each of the alternatives is attributed with the utility score, which is obtained as the average of the two normalized aggregates:

$$
A S_{i}=\frac{1}{2}\left(N S P_{i}+N S N_{i}\right)
$$

where $0 \leq A S_{i} \leq 1$.

Step 7. The alternatives are ranked in descending order of the utility scores from Step 6.

\subsection{WASPAS-N Method}

The weighted aggregated sum product assessment (WASPAS) technique is based on two types of aggregation, namely the weighted sum and weighted product model $[30,76]$. Indeed, these two concepts are related to the arithmetic and geometric means, respectively. The combination of the two 
approaches is appealing in the context of the measurement of sustainability, as the weighted arithmetic mean allows for complete substitution among the arguments (criteria in the case of MCDM), whereas the substitution is limited in the case of the weighted geometric mean. The combination of the two approaches, therefore, offers an intermediate case. The WASPAS technique has been applied for energy system management [77,78], third-party logistics providers [79] and indoor construction [80], among others. Jahan [81] extended the WASPAS technique for target-based normalization.

The use of the arithmetic and geometric means involves certain methodological issues. Specifically, the geometric mean is not greater than the arithmetic mean. Therefore, we modify the WASPAS technique and propose normalizing the two means with respect to the maximum values. We term the proposed technique WASPAS-N.

Step 1. The MCDM problem is formulated as a decision matrix as follows:

$$
X=\left[\begin{array}{cccc}
x_{11} & x_{12} & \cdots & x_{1 m} \\
x_{21} & x_{22} & \cdots & x_{2 m} \\
\cdots & \cdots & \cdots & \cdots \\
x_{n 1} & x_{n 2} & \cdots & x_{n m}
\end{array}\right]
$$

where the number of alternatives is represented by $n$ and the number of criteria is given by $m ; x_{i j}$ denotes the rating of alternative $i$ against criterion $j$.

Step 2. The decision matrix $X$ is normalized by applying the linear normalization. This procedure depends on the type of criteria.

For benefit criteria,

$$
\bar{x}_{i j}=\frac{x_{i j}}{\max _{i} x_{i j}}
$$

and for cost criteria,

$$
\bar{x}_{i j}=\frac{\min _{i} x_{i j}}{x_{i j}}
$$

where $\bar{x}_{i j}$ is the normalized value of $x_{i j}$.

Step 3. The WASPAS relies on the arithmetic and geometric weighted means. The relative additive utility of the $i$-th alternative is obtained as the weighted arithmetic mean:

$$
Q_{i}^{(1)}=\sum_{j=1}^{m} \bar{x}_{i j} w_{j}
$$

where the importance of the $j$-th criterion is represented by $w_{j}$.

The relative multiplicative utility of the $i$-th alternative is obtained as the weighted geometric mean:

$$
Q_{i}^{(2)}=\prod_{j=1}^{m}\left(\bar{x}_{i j}\right)^{w_{j}}
$$

Step 4. We then offer a modified calculation procedure to account for different levels of the arithmetic and geometric means by calculating the overall relative utility as follows:

$$
Q_{i}=\frac{0.5 Q_{i}^{(1)}}{\max _{i} Q_{i}^{(1)}}+\frac{0.5 Q_{i}^{(2)}}{\max _{i} Q_{i}^{(2)}}
$$

Step 5. The alternatives are ordered in descending order of $Q_{i}$. 


\subsection{Sensitivity Analysis}

It is known that a number of factors can affect the outcomes of MCDM, and one of the major factors is the weights of criteria. Due to the necessity to ascertain if the alterations in weight vector induce alterations in the resulting orderings of the alternatives, one can apply multiple weighting schemes. What is more, the stability of the analysis may be impacted by the number of criteria and alternatives. Because of the difficulties of modeling and reporting these relationships, the robustness of the MCDM-based ranking is tested by exploiting the Monte Carlo procedure. Here, the Monte Carlo technique is utilized due to the need to know whether modifications in criteria weights can impact the consistency of the results. In this paper, we assume that criteria weights are derived from variables randomly drawn from a uniform distribution:

$$
\omega_{j}^{b} \stackrel{i . i . d}{\sim} U(0,1)
$$

where $b=1,2, \ldots, B$ keeps track of the Monte Carlo replications, $B$ denotes the total number of replications carried out, and i.i.d. means identically and independently distributed. Accordingly, the Monte Carlo procedure generates $B$ vectors of values used to derive the weights based on the uniform distribution. The following formula shows how the elements within the draws are normalized:

$$
w_{j}^{b}=\frac{\omega_{j}^{b}}{\sum_{j=1}^{n} \omega_{j}^{b}}, b=1,2, \ldots, B
$$

The resulting values $w_{j}^{b}$ then serve as the weights of criteria in replication $b$. In this paper, we use $B=1000$.

\section{Results}

This section presents results of the analysis. We include the decision matrix in this section as it required much additional research when combining different sources of information. We then proceed to the ranking of the alternative locations by applying the two MCDM techniques. The ranking based on Monte Carlo simulation is contrasted to the one based on the expert survey.

\subsection{Construction of the Decision Matrix}

The criteria and the associated directions of optimization (minimization or maximization) for location selection of a teahouse are displayed in Table 2. We chose Vilnius, the capital city of Lithuania, as the case study, as this is the most appealing option for investment given the development trends of the economy and population flows. Six alternative locations were identified for consideration when locating a teahouse: Location 1-space for rent on Aušros Vartu Street, Location 2-space for rent in Vilniaus Street, Location 3-space for rent in Dominikonu Street, Location 4-space for rent in Vingriu Street, Location 5-space for rent in Bazilijonu Street, and Location 6-space for rent in Didžioji Street.

The decision matrix was then established by assigning the criterion values for each alternative (Table 3). The data on rent cost, property area, and parking capacity criteria were collected from the official website for the advertisement of premises to let in Vilnius (Aruodas.lt). The data on pedestrian flow were collected from JCDecaux pedestrian flow research based on expert evaluations. The data on public transportation were collected by counting the frequency of buses and trolleybuses stopping by the alternatives per day (Trafi.lt). The data on distances to sceneries and public facilities were collected by measuring the distances on the virtual Vilnius map (maps.vilnius.lt). The data on the distances to garbage containers were collected by measuring the distances on the virtual map of the garbage containers in Vilnius (gis.v-planas.com). The data on the number of crimes were collected by counting the number of crimes on the virtual map of crime activity in Vilnius (ird.lt). The data 
on outdoor advertisement possibilities were collected by the virtue of the interactive map of Vilnius (maps.vilnius.lt).

Table 2. Criteria and directions of optimization for the teahouse location selection.

\begin{tabular}{|c|c|c|}
\hline Crtiterion & Description (Dimension) & $\begin{array}{l}\text { Direction of } \\
\text { Optimization }\end{array}$ \\
\hline Rent cost $(€ /$ month $)$ & Cost for the building (inner space) ( $€ /$ month) & Min \\
\hline Property area $\left(\mathrm{m}^{2}\right)$ & The inner space of the area for rent $\left(\mathrm{m}^{2}\right)$ & Max \\
\hline Distance to scenery $(\mathrm{m})$ & Distance near by the scenery $(\mathrm{m})$ & Min \\
\hline $\begin{array}{l}\text { Public transportation } \\
\text { (frequency per day) }\end{array}$ & $\begin{array}{l}\text { The frequency of bus and trolley routes } \\
\text { within } 500 \mathrm{~m} \text { (frequency per day) }\end{array}$ & Max \\
\hline Pedestrian flow (people per hour) & $\begin{array}{l}\text { The number of pedestrians passing by the } \\
\text { teahouse (people per hour) }\end{array}$ & Max \\
\hline Parking capacity (number of lots) & $\begin{array}{l}\text { The number of parking units within } 500 \mathrm{~m} \\
\text { (number of lots) }\end{array}$ & Max \\
\hline Number of competitors & The number of similar cafes within $500 \mathrm{~m}$ & Min \\
\hline $\begin{array}{l}\text { Number of crimes in the } \\
\text { surrounding area }\end{array}$ & $\begin{array}{l}\text { Cases of a criminal offense within } 500 \mathrm{~m} \\
\text { (number per month) }\end{array}$ & Min \\
\hline Distance to public facilities (m) & $\begin{array}{l}\text { Average distance to the public facilities } \\
\text { (education institutions, residential buildings, } \\
\text { public libraries, bus/train stations) (m) }\end{array}$ & Min \\
\hline Outdoor advertisement $\left(\mathrm{m}^{2}\right)$ & $\begin{array}{c}\text { The geographical extent of commercial area, } \\
\text { where teahouse can legally advertise in their } \\
\text { outer place }\left(\mathrm{m}^{2}\right)\end{array}$ & Max \\
\hline Distance to garbage containers (m) & Distance to the garbage containers (m) & Min \\
\hline
\end{tabular}

Table 3. Initial decision-making matrix.

\begin{tabular}{|c|c|c|c|c|c|c|c|c|}
\hline Criterion & Direction & Weight & $\begin{array}{c}\text { Location } \\
1\end{array}$ & $\begin{array}{c}\text { Location } \\
2\end{array}$ & $\begin{array}{c}\text { Location } \\
3\end{array}$ & $\begin{array}{c}\text { Location } \\
4\end{array}$ & $\begin{array}{c}\text { Location } \\
5\end{array}$ & $\begin{array}{c}\text { Location } \\
6\end{array}$ \\
\hline Rent cost $(€ /$ month $)$ & Min & 0.14 & 1491 & 1746 & 5962 & 2404 & 1289 & 3529 \\
\hline Property area $\left(\mathrm{m}^{2}\right)$ & Max & 0.12 & 67 & 225 & 104 & 104 & 76 & 170 \\
\hline Distance to scenery (m) & Min & 0.08 & 300 & 200 & 450 & 700 & 270 & 100 \\
\hline Public transportation (frequency per day) & $\operatorname{Max}$ & 0.06 & 183 & 539 & 161 & 368 & 130 & 71 \\
\hline Pedestrian flow (people per hour) & Max & 0.13 & 5830 & 13,710 & 6880 & 3170 & 6410 & 9170 \\
\hline Parking capacity (number of lots) & Max & 0.12 & 60 & 74 & 82 & 56 & 65 & 80 \\
\hline Number of competitors & Min & 0.13 & 7 & 18 & 6 & 5 & 3 & 11 \\
\hline Number of crimes in the surrounding area & Min & 0.05 & 25.5 & 32.5 & 37.5 & 34.5 & 33 & 27 \\
\hline Distance from public facilities (m) & Min & 0.06 & 390.6 & 827.8 & 691.6 & 391.8 & 260.6 & 421 \\
\hline Outdoor advertisement $\left(\mathrm{m}^{2}\right)$ & Max & 0.06 & 170 & 375 & 225 & 189 & 192 & 398 \\
\hline Distance from garbage containers (m) & Min & 0.03 & 30 & 10 & 15 & 40 & 10 & 60 \\
\hline
\end{tabular}

Note: the weights of criteria were provided by the expert survey.

After constructing the matrix, the weights of criteria were calculated and further analysis was carried out both by using the ratings provided by the experts (the questionnaire was based on the Likert scale) and by applying the Monte Carlo simulation procedure to the WASPAS method and EDAS method. In this research, EDAS and WASPAS methods were applied by using Monte Carlo simulation and expert survey weights. Using the previously presented procedures for implementation of the WASPAS and EDAS methods, the optimal solution for the case study was determined, and the results based on each of the methods were compared.

\subsection{Ranking the Alternatives}

The WASPAS and EDAS techniques were applied without assuming any specific weight vectors during the Monte Carlo procedure. The results are given in Table 4. As it was stated before, the uniform distribution was applied in order to generate the weights. The rows in Table 4 represent the ranks 
assigned for different alternatives during the Monte Carlo simulation, whereas the columns represent different locations considered in the MCDM problem. The most preferable location is attributed with rank 1 . Therefore, higher values within the cells indicate higher probabilities for assigning a certain rank for a particular location.

Table 4. Changes in ranking during the Monte Carlo simulation (1000 replications).

\begin{tabular}{|c|c|c|c|c|c|c|c|}
\hline \multirow{2}{*}{ Rank } & \multicolumn{6}{|c|}{ Alternatives } & \multirow{2}{*}{ Stability } \\
\hline & Location 1 & Location 2 & Location 3 & Location 4 & Location 5 & Location 6 & \\
\hline \multicolumn{8}{|c|}{ WASPAS } \\
\hline 1 & 0 & 743 & 0 & 0 & 230 & 27 & 0.74 \\
\hline 2 & 0 & 231 & 0 & 1 & 587 & 181 & 0.59 \\
\hline 3 & 147 & 25 & 34 & 47 & 180 & 567 & 0.57 \\
\hline 4 & 577 & 0 & 199 & 106 & 3 & 115 & 0.58 \\
\hline 5 & 218 & 1 & 349 & 359 & 0 & 73 & 0.36 \\
\hline 6 & 58 & 0 & 418 & 487 & 0 & 37 & 0.49 \\
\hline Stability & 0.58 & 0.74 & 0.42 & 0.49 & 0.59 & 0.57 & \\
\hline \multicolumn{8}{|c|}{ EDAS } \\
\hline 1 & 0 & 741 & 0 & 0 & 231 & 28 & 0.74 \\
\hline 2 & 21 & 210 & 2 & 11 & 595 & 161 & 0.60 \\
\hline 3 & 485 & 37 & 49 & 43 & 167 & 219 & 0.49 \\
\hline 4 & 424 & 7 & 105 & 180 & 7 & 277 & 0.42 \\
\hline 5 & 66 & 4 & 341 & 390 & 0 & 199 & 0.39 \\
\hline 6 & 4 & 1 & 503 & 376 & 0 & 116 & 0.50 \\
\hline Stability & 0.49 & 0.74 & 0.50 & 0.39 & 0.60 & 0.28 & \\
\hline
\end{tabular}

Note: the highest frequencies are boldfaced for each column; stability represents the maximum frequency normalized to the number of Monte Carlo replications (applied for columns and rows). WASPAS: weighted aggregated sum product assessment method; and EDAS: evaluation based on distance from average solution method.

By considering the highest frequencies observed within each column in Table 4, one can establish the most probable ranking in case the weights are perturbed. Obviously, the rankings present in Table 4 induce no conflicting situations among the alternatives as each column has unique most probable value (rank) independently on the MCDM technique applied. The results indicate that stability of the most preferable alternative is rather high $(74 \%)$ for both MCDM techniques. In both cases, Location 1 is identified as the most preferable alternative. The probability of ranking Location 1 as the second most preferable alternative is 0.23 for the WASPAS technique and 0.21 for the EDAS technique. In the case of the WASPAS technique, the ranking of Locations 3 and 4 is the least certain as the corresponding stabilities are below 50\%). In the case of the EDAS method, the ranking of Locations 1, 4, and 6 turned out to be the least certain (the stability was below 50\%). In particular, the ranking of Location 4 under the EDAS technique suggested a scattered pattern. These results indicate that the use of single MCDM technique and single weight vector might render the ranking unreliable.

Besides the Monte Carlo simulation, we also opted for the expert survey. A total of five experts holding executive positions in the real estate or hospitality sector with work experience of not less than 10 years was surveyed. They were asked to rate the importance of the criteria considered on a five-point Likert scale. The resulting average scores were normalized with respect to their sum in order to retrieve the resulting weight vector (Table 3 presents the resulting weights). The rankings based on the Monte Carlo procedure and expert survey are summarized in Table 5.

As one can note from Table 5, both the Monte Carlo simulation and the expert survey resulted in the same optimal solution: Location 2 was identified as the most preferable location for a teahouse. Indeed, Location 2 is located on Vilnius Street. The pedestrian flow per day is the highest there. What is more, the property area and public transportation frequency showed good performance of this particular alternative. We can see the difference between the Monte Carlo simulation for WASPAS and Monte Carlo simulation for EDAS with regards to ranks 4-6. The results based on the weights provided 
by the expert survey are invariant to the choice of the MCDM technique. In any case, Location 2 remained the most preferable one.

Table 5. Location rankings based on the WASPAS and EDAS methods with the weights obtained from the expert survey and Monte Carlo simulation.

\begin{tabular}{ccccc}
\hline \multirow{2}{*}{ Alternatives } & \multicolumn{2}{c}{ WASPAS } & \multicolumn{2}{c}{ EDAS } \\
\cline { 2 - 5 } & Expert Survey & Monte Carlo & Expert Survey & Monte Carlo \\
\hline Location 1 & 4 & 6 & 4 & 4 \\
Location 2 & 1 & 1 & 1 & 1 \\
Location 3 & 6 & 5 & 6 & 6 \\
Location 4 & 5 & 4 & 5 & 5 \\
Location 5 & 2 & 3 & 2 & 3 \\
Location 6 & 3 & 2 & 3 & 2 \\
\hline
\end{tabular}

\section{Conclusions}

This study presented the case of MCDM application to teahouse location selection in Vilnius, Lithuania. The results of the research are important as the tea market is not as saturated yet as compared with the substitute markets (e.g., coffee market) in Lithuania. From the theoretical viewpoint, the present study revises the WASPAS technique and proposes WASPAS-N involving normalization of the additive and multiplicative utility functions.

The empirical results of the present study are of importance for prospective investors, entrepreneurs, and enterprisers. More specifically, the set of criteria that determine the success of the possible locations for a teahouse has been established. The proposed framework allows imputing the data available and comprehensively comparing the possible alternatives for the future business plans.

The proposed research framework involved the two MCDM methods (i.e., WASPAS and EDAS). The application of the two methods allowed us to increase the robustness of the analysis. The same objective was further tackled by implementing the sensitivity analysis based on the Monte Carlo simulation.

Several possible locations in Vilnius were considered in the empirical analysis. By applying the developed framework and collecting the relevant data from multiple information sources, the most promising alternatives have been identified. It turned out that the city center is where the most appealing alternative for a teahouse is located (Location 2, Vilnius Str.). Specifically, the latter location features the highest pedestrian flow and public transportation frequency when compared with the other alternatives. Also, the largest area is available in this instance.

The results indicate that the optimal decision does not depend on the technique applied (i.e., WASPAS or EDAS). What is more, the same results are obtained if weights provided by the experts are applied rather than assuming random weights during the Monte Carlo simulation. Therefore, the results are robust to both random changes in the weights and switching from random weighting to expert survey.

As regards further research, fuzzy logics could be involved in the analysis to allow for the use of imprecise data. Such an approach would allow the capturing of more complex information patterns when solving economic problems. On the other hand, different MCDM techniques can be applied for further analysis, especially those based on mathematical programming (weighted-sum approach, reference point method, or lexicographic approach). In this paper, we considered eleven criteria for choosing the optimal location for a teahouse. This allows the considering of multiple facets of the location selection problem. However, some criteria might provide little additional information (i.e., redundant criteria might appear). In the future research, the sensitivity analysis could aim at checking the impacts of the reduction of the number of criteria. 
Author Contributions: Conceptualization, T.B.; Funding acquisition, J.C.; Investigation, F.Z.; Methodology, T.B.; Writing of original draft, F.Z.; Review and editing of manuscript, J.C., D.S., J.W., and D.M.

Funding: This work was funded by the projects of the National Social Science Fund of China (No. 16ZDA053, No. 16BTJ026, No. 17CTJ012).

Conflicts of Interest: The authors declare no conflicts of interest.

\section{References}

1. Pjerotic, L.; Delibasic, M.; Joksiene, I.; Griesiene, I.; Georgeta, C.P. Sustainable tourism development in the rural areas. Transform. Bus. Econ. 2017, 16, 21-30.

2. Ruzic, P.; Demonja, D. Economic impacts of rural tourism in rural areas of Istria (Croatia). Transform. Bus. Econ. 2017, 16, 31-41.

3. Chirenje, L.I. Contribution of ecotourism to poverty alleviation in Nyanga, Zimbabwe. Chin. J. Popul. Resour. Environ. 2017, 15, 87-92. [CrossRef]

4. Chaudhary, R.; Bisai, S. Factors influencing green purchase behavior of millennials in India. Manag. Environ. Q. 2018, 29, 798-812. [CrossRef]

5. Statista. Annual Turnover of the Food and Beverage Service Activities Industry in Lithuania from 2008 to 2014 (in Million Euros). 2018. Available online: https:/ / www.statista.com/statistics/410422/turnover-foodbeverage-service-lithuania/ (accessed on 25 May 2018).

6. Lithuanian Institute of Agrarian Economics. Agricultural and Food Sector in Lithuania; Lithuanian Institute of Agrarian Economics: Vilnius, Lithuania, 2015; ISSN 2351-6321.

7. Statista. Highlights: Lithuania. 2018. Available online: https://www.statista.com/outlook/30020000/143/ tea/lithuania\# (accessed on 26 May 2018).

8. Nielsen. Lietuvoje Kava Prieš Arbatą Laimi Triuškinančiu Santykiu. 2016. Available online: http:/ /www.nielsen. com/lt/lt/press-room/2016/lietuvoje-kava-pries-arbata-laimi-triuskinanciu-santykiu.html (accessed on 26 May 2018).

9. Kaviniu Rinkoje Nèra Vietos Net Pačiam “Starbucks". Lietuvos Rytas. 2015. Available online: https:/ verslas. lrytas.lt/rinkos-pulsas/2015/06/09/news/kaviniu-rinkoje-nera-vietos-net-paciam-starbucks--3628266/ (accessed on 26 May 2018).

10. Gardner, E.J.; Ruxton, C.H.S.; Leeds, A.R. Black tea-helpful or harmful? A review of the evidence. Eur. J. Clin. Nutr. 2007, 61, 3. [CrossRef] [PubMed]

11. Ek, W.E.; Tobi, E.W.; Ahsan, M.; Lampa, E.; Ponzi, E.; Kyrtopoulos, S.A.; Georgiadis, P.; Lumey, L.H.; Heijmans, B.T.; Botsivali, M.; et al. Tea and coffee consumption in relation to DNA methylation in four European cohorts. Hum. Mol. Genet. 2017, 26, 3221-3231. [CrossRef] [PubMed]

12. Sennaroglu, B.; Celebi, G.V. A military airport location selection by AHP integrated PROMETHEE and VIKOR methods. Transp. Res. Part D Transp. Environ. 2018, 59, 160-173. [CrossRef]

13. Nguyen Anh, T.; Hoang Thi, H. Distribution center location selection using an extension of fuzzy TOPSIS Approach. Int. J. Supply Chain Manag. 2017, 6, 83-89.

14. Chang, K.L.; Liao, S.K.; Tseng, T.W.; Liao, C.Y. An ANP based TOPSIS approach for Taiwanese service apartment location selection. Asia Pac. Manag. Rev. 2015, 20, 49-55. [CrossRef]

15. Ertuğrul, İ.; Karakaşoğlu, N. Comparison of fuzzy AHP and fuzzy TOPSIS methods for facility location selection. Int. J. Adv. Manuf. Technol. 2008, 39, 783-795. [CrossRef]

16. Hu, K.H.; Jianguo, W.; Tzeng, G.H. Improving China's regional financial center modernization development using a new hybrid MADM model. Technol. Econ. Dev. Econ. 2018, 24, 429-466. [CrossRef]

17. Yıldız, N.; Tüysüz, F. A hybrid multi-criteria decision making approach for strategic retail location investment: Application to Turkish food retailing. Socio-Econ. Plan. Sci. 2018. [CrossRef]

18. Yu, S.M.; Wang, J.; Wang, J.Q.; Li, L. A multi-criteria decision-making model for hotel selection with linguistic distribution assessments. Appl. Soft Comput. 2018, 67, 741-755. [CrossRef]

19. Chou, T.Y.; Hsu, C.L.; Chen, M.C. A fuzzy multi-criteria decision model for international tourist hotels location selection. Int. J. Hosp. Manag. 2008, 27, 293-301. [CrossRef]

20. Genç, T.; Filipe, J.A. A fuzzy MCDM approach for choosing a tourism destination in Portugal. Int. J. Bus. Syst. Res. 2016, 10, 23-44. [CrossRef] 
21. Fadafan, F.K.; Danehkar, A.; Pourebrahim, S. Developing a non-compensatory approach to identify suitable zones for intensive tourism in an environmentally sensitive landscape. Ecol. Indic. 2018, 87, 152-166. [CrossRef]

22. Liu, C.H.; Tzeng, G.H.; Lee, M.H. Improving tourism policy implementation-The use of hybrid MCDM models. Tour. Manag. 2012, 33, 413-426. [CrossRef]

23. Doumpos, M.; Grigoroudis, E. Multicriteria Decision Aid and Artificial Intelligence: Links, Theory and Applications; Wiley-Blackwell: Hoboken, NJ, USA, 2013; p. 368.

24. Ballestero, E.; Romero, C. Multiple Criteria Decision Making and Its Applications to Economic Problems; Stringe: Berlin, Germany, 1998.

25. Kumar, A.; Sah, B.; Singh, A.R.; Deng, Y.; He, X.; Kumar, P.; Bansal, R.C. A review of multi criteria decision making (MCDM) towards sustainable renewable energy development. Renew. Sustain. Energy Rev. 2017, 69, 596-609. [CrossRef]

26. Løken, E. Use of multicriteria decision analysis methods for energy planning problems. Renew. Sustain. Energy Rev. 2007, 11, 1584-1595. [CrossRef]

27. McCrimmon, K.R. Decision making among multiple-attribute alternatives: Survey and consolidated approach. In RAND Memorandum; RAND Corporation: Santa Monica, CA, USA, 1968.

28. Bridgman, P.W. Dimensional Analysis; Yale University Press: New Haven, CT, USA, 1922.

29. Keeney, R.L.; Raiffa, H. Decisions with Multiple Objectives; John Wiley and Sons: New York, NY, USA, 1976.

30. Zavadskas, E.K.; Turskis, Z.; Antucheviciene, J.; Zakarevicius, A. Optimization of weighted aggregated sum product assessment. Elektronika ir Elektrotechnika 2012, 122, 3-6. [CrossRef]

31. Saaty, T.L. The Analytic Hierarchy Process; McGraw-Hill: New York, NY, USA, 1980.

32. Guitouni, A.; Martel, J.-M. Tentative guidelines to help choosing an appropriate MCDA method. Eur. J. Oper. Res. 1998, 109, 501-521. [CrossRef]

33. Yoon, K.P.; Hwang, C.L. Multiple Attribute Decision Making: An Introduction; Sage Publications: Thousand Oaks, CA, USA, 1995; Volume 104.

34. Opricović, S. Višekriterijumska Optimizacija Sistema u Građevinarstøu; Građevinski fakultet Univerziteta: Sarajevo, Bosnia and Herzegovina, 1998.

35. Brauers, W.K.; Zavadskas, E.K. The MOORA method and its application to privatization in a transition economy. Control. Cybern. 2006, 35, 445-469.

36. Keshavarz Ghorabaee, M.; Zavadskas, E.K.; Olfat, L.; Turskis, Z. Multi-criteria inventory classification using a new method of evaluation based on distance from average solution (EDAS). Informatica 2015, 26, 435-451. [CrossRef]

37. Roy, B. The outranking approach and the foundations of ELECTRE methods. In Readings in Multiple Criteria Decision Aid; Springer: Berlin/Heidelberg, Germany, 1990; pp. 155-183.

38. Brans, J.P.; Mareschal, B.; Vincke, P. PROMETHEE: A new family of outranking methods in multicriteria analysis. In Operational Research_84; Brans, J.P., Ed.; North-Holland: New York, NY, USA, 1984; pp. 477-490.

39. Marler, R.T.; Arora, J.S. Survey of multi-objective optimization methods for engineering. Struct. Multidiscip. Optim. 2004, 26, 369-395. [CrossRef]

40. Romero, C.; Tamiz, M.; Jones, D. Goal programming, compromise programming and reference point method formulations: Linkages and utility interpretations. J. Oper. Res. Soc. 1998, 49, 986-991. [CrossRef]

41. Sawik, B. Lexicographic and weighting approach to multi-criteria portfolio optimization by mixed integer programming. In Financial Modeling Applications and Data Envelopment Applications; Emerald Group Publishing Limited: Bingley, UK, 2009; pp. 3-18.

42. Sawik, B. Application of multi-criteria mathematical programming models for assignment of services in a hospital. In Applications of Management Science; Emerald Group Publishing Limited: Bingley, UK, 2013; pp. 39-53.

43. Sawik, B. Weighted-sum approach for bi-objective optimization of fleet size with environmental aspects. In Applications of Management Science; Emerald Publishing Limited: Bingley, UK, 2018; pp. 101-116.

44. Diaz-Balteiro, L.; González-Pachón, J.; Romero, C. Measuring systems sustainability with multi-criteria methods: A critical review. Eur. J. Oper. Res. 2017, 258, 607-616. [CrossRef]

45. Zavadskas, E.K.; Turskis, Z. Multiple criteria decision making (MCDM) methods in economics: An overview. Technol. Econ. Dev. Econ. 2011, 17, 397-427. [CrossRef] 
46. Song, M.L.; Fisher, R.; Wang, J.L.; Cui, L.B. Environmental performance evaluation with big data: Theories and methods. Ann. Oper. Res. 2018, 1-14. [CrossRef]

47. Song, M.; Peng, J.; Wang, J.; Dong, L. Better resource management: An improved resource and environmental efficiency evaluation approach that considers undesirable outputs. Resour. Conserv. Recycl. 2018, 128, 197-205. [CrossRef]

48. Chen, C.T. A fuzzy approach to select the location of the distribution center. Fuzzy Set. Syst. 2001, 118, 65-73. [CrossRef]

49. Cagri Tolga, A.; Tuysuz, F.; Kahraman, C. A fuzzy multi-criteria decision analysis approach for retail location selection. Int. J. Inf. Technol. Decis. Mak. 2013, 12, 729-755. [CrossRef]

50. Tzeng, G.-H.; Teng, M.-H.; Chen, J.-J.; Opricovic, S. Multicriteria Selection for a Restaurant Location in Taipei. Hosp. Manage. 2002, 21, 171-187. [CrossRef]

51. Ziemba, P.; Watróbski, J.; Zioło, M.; Karczmarczyk, A. Using the PROSA Method in Offshore Wind Farm Location Problems. Energies 2017, 10, 1755. [CrossRef]

52. Ziemba, P. NEAT F-PROMETHEE-A new fuzzy multiple criteria decision making method based on the adjustment of mapping trapezoidal fuzzy numbers. Expert Syst. Appl. 2018, 110, 363-380. [CrossRef]

53. Jovanovic, D.M. Planning of optimal location and sizes of distribution transformers using integer programming. Int. J. Electr. Power Energy Syst. 2003, 25, 717-723. [CrossRef]

54. Cheng, W.L.; Li, H. Exploring quantitative methods for project location selection. Concurr. Eng. 2004, 21, $237-251$.

55. Bhaumik, P. Optimal shrinking of the distribution chain: The facilities delocation decision. Int. J. Syst. Sci. 2010, 41, 271-280. [CrossRef]

56. Tzeng, G.H.; Chen, Y.W. The optimal location of airport fire stations: A fuzzy multi-objective programming and revised genetic algorithm approach. Transp. Plan. Technol. 2007, 23, 37-55. [CrossRef]

57. Arora, S.; Arora, S.R. Multiobjective capacitated plant location problem. Int. J. Oper. Res. 2010, 7, 487-505. [CrossRef]

58. Serrano-Hernandez, A.; Faulin, J.; Pintor, J.M.; Belloso, J. Determining an optimal area to locate a biorefinery under economic and environmental criteria. Transp. Res. Procedia 2017, 22, 95-104. [CrossRef]

59. Ho, H.P.; Chang, C.T.; Ku, C.Y. On the location selection problem using analytic hierarchy process and multi-choice goal programming. Int. J. Syst. Sci. 2013, 44, 94-108. [CrossRef]

60. Nelson, R.L. The Selection of Retail Location; McGraw-Hill: New York, NY, USA, 1958.

61. Applebaum, W.; Cohen, S.B. Evaluating store sites and determining store rents. Econ. Geogr. 2016, 36, 1-35.

62. Jain, A.K.; Mahajan, V. Evaluating the Competitive Environment in Retailing Using Multiplicative Competitive Interactive Models; Research in Marketing; JAI Press: Greenwich, CT, USA, 1979.

63. Hing, N.; Lee, Y.L. Measuring quality in restaurant operations: an application of the SERVQUAL instrument. Int. J. Hosp. Manag. 1995, 14, 293-310.

64. Olsen, M.D.; Roper, A. Research in strategic management in the hospitality industry. Int. J. Hosp. Manag. 1998, 17, 111-124. [CrossRef]

65. Kuo, R.J.; Chi, S.C.; Kao, S.S. A decision support system for selecting convenience store location through integration of fuzzy AHP and artificial neural network. Comput. Ind. 2002, 64, 199-214. [CrossRef]

66. Kolli, S.; Evans, G.W. A multiple objective integer programming approach for planning franchise expansion. Comput. Ind. Eng. 1999, 37, 543-561. [CrossRef]

67. Harvard Business School. Note on Facility Location; Harvard Business School: Boston, MA, USA, 1989.

68. Ghosh, A.; Harche, F. Location-allocation models in the private sector: Progress, problems, and prospects. Locat. Sci. 1993, 1, 81-106.

69. Raubal, M.; Rinner, C. Multi-criteria decision analysis for location based services. In Proceedings of the 12th International Conference on Geoinformatics-Geospatial Information Research: Bridging the Pacific and Atlantic University of Gävle, Gävle, Sweden, 7-9 June 2004.

70. Melo, M.T.; Nickel, S.; Saldanha-da-Gama, F. Facility location and supply chain management-A review. Eur. J. Oper. Res. 2009, 196, 401-412. [CrossRef]

71. Carver, S.J. Integrating multi-criteria evaluation with geographical information systems. Int. J. Geogr. Inf. Syst. 1991, 5, 321-329. [CrossRef]

72. Stull, W.J. Community environment, zoning, and the market value of single-Family home. J. Law Econ. 1970, 18, 535-557. [CrossRef] 
73. Law, R.; To, T.; Goh, C. How do mainland Chinese travelers choose restaurants in Hong Kong? An exploratory study of individual visit scheme travelers and packaged travelers. Int. J. Hosp. Manag. 2008, 27, 346-354. [CrossRef]

74. Kim, S.-S.; Yang, I.-H.; Yeo, M.-S.; Kim, K.-W. Development of a housing performance evaluation model for multi-family residential buildings in Korea. Build. Environ. 2005, 40, 1103-1116. [CrossRef]

75. Keshavarz Ghorabaee, M.; Amiri, M.; Olfat, L.; Khatami Firouzabadi, S.M.A. Designing a multi-product multi-period supply chain network with reverse logistics and multiple objectives under uncertainty. Technol. Econ. Dev. Econ. 2017, 23, 520-548. [CrossRef]

76. Zavadskas, E.K.; Turskis, Z.; Antucheviciene, J. Selecting a contractor by using a novel method for multiple attribute analysis: Weighted Aggregated Sum Product Assessment with grey values (WASPAS-G). Stud. Inf. Control 2015, 24, 141-150.

77. Džiugaitè-Tumènienè, R.; Lapinskienė, V. The multicriteria assessment model for an energy supply system of a low energy house. Eng. Struct. Technol. 2014, 6, 33-41. [CrossRef]

78. Vafaeipour, M.; Zolfani, S.H.; Derakhti, A.; Eshkalag, M.K. Assessment of regions priority for implementation of solar projects in Iran: New application of a hybrid multi-criteria decision making approach. Energ. Convers. Manag. 2014, 86, 653-663. [CrossRef]

79. Ghorabaee, M.K.; Amiri, M.; Zavadskas, E.K.; Antuchevičienè, J. Assessment of third-party logistics providers using a CRITIC-WASPAS approach with interval type-2 fuzzy sets. Transport 2017, 32, 66-78. [CrossRef]

80. Zavadskas, E.K.; Kalibatas, D.; Kalibatiene, D. A multi-attribute assessment using WASPAS for choosing an optimal indoor environment. Arch. Civ. Mech. Eng. 2016, 16, 76-85. [CrossRef]

81. Jahan, A. Developing WASPAS-RTB method for range target-based criteria: Toward selection for robust design. Technol. Econ. Dev. Econ. 2018, 24, 1362-1387. [CrossRef]

(C) 2018 by the authors. Licensee MDPI, Basel, Switzerland. This article is an open access article distributed under the terms and conditions of the Creative Commons Attribution (CC BY) license (http:/ / creativecommons.org/licenses/by/4.0/). 